\title{
Water-Quality Assessment of the San Joaquin-Tulare Basins Entering a New Decade
}

\section{Introduction to NAWQA}

In 1991, the National Water-Quality Assessment (NAWQA) Program of the U.S. Geological Survey began to address the need for consistent and scientifically sound information for managing the Nation's water resources. The longterm goals of this program are to assess the status of the quality of freshwater streams and aquifers, to describe trends or changes in water quality over time, and to provide a sound understanding of the natural and human factors that affect the quality of these resources (Hirsch and others, 1988). Investigations are being conducted within major river basins and aquifer systems, or "study units," throughout the Nation to provide a framework for national and regional water-quality assessments.

In 2001, the NAWQA Program began its second decade of intensive water-quality assessments. Forty-two of the original 59 study units (reduced by elimination or combination) are being revisited (Gilliom and others, 2001). The San Joaquin-Tulare Basins study unit (fig. 1), located in central California, was a part of the first decadal cycle of the Program investigations and remains in the second cycle.

The three goals upon which the Program was based remain the foundation of the national assessment in the second cycle. During the second cycle, less emphasis, however, will be placed on assessing the status of water-quality conditions because of substantial advances made in the assessments during the first cycle. The focus of the new status assessments will be on sampling water quality in geographic regions not sampled during the first cycle and on analyzing selected constituents not analyzed during the first cycle.

More emphasis will be placed on describing long-term trends and on understanding human and natural factors that control water quality. Long-term trends will be studied by resampling stream and well sites established in the first cycle. Understanding factors that control water quality will be addressed in five topical studies that will study the link between sources and transport processes, and potential effects of contaminants on humans and aquatic ecosystems. This information will provide a scientific basis for water-quality management and the possibility of extrapolating to other unmonitored areas. The five topical studies are:

1. Effects of nutrient enrichment on stream ecosystems.

2. Agricultural chemicals: sources, transport, and fate.

3. Transport of anthropogenic and natural contaminants to community supply wells.

4. Effects of urbanization on stream ecosystems.

5. Mercury bioaccumulation in stream ecosystems.

\section{National Water-Quality Assessment Goals}

The goals of NAWQA are to assess the status and trends of water quality and to understand the factors that affect it, thus addressing the questions:

- What is the condition of our Nation's streams and ground water?

- How is water quality changing over time?

- How do natural features and human activities affect the quality of streams and ground water?
The purpose of this report is to describe what has been and will be done in the second cycle of the NAWQA Program in the San Joaquin-Tulare Basins study unit. Results from the first cycle are summarized in Dubrovsky and others (1998).

\section{Introduction to the San Joaquin- Tulare Basins study}

The San Joaquin-Tulare Basins study unit (fig. 1) is approximately 31,200 square miles; it includes the San Joaquin Valley, the eastern slope of the Coast Ranges, and the western slope of the Sierra Nevada. The Sierra Nevada is predominantly forested land, and the Coast Ranges and the foothills of the Sierra Nevada are predominantly rangeland. Most of the valley floor is used for agriculture. About 10 percent of the total value of agricultural production in the United States comes from California, with the San Joaquin Valley producing about half of the California total. Changes in water quality in the San Joaquin-Tulare Basins are primarily due to the large amount of irrigated agriculture, which affects the quality of both surface and ground water in the valley (Gronberg and others, 1998).

\section{Activities of Second Cycle}

As part of the second cycle of NAWQA assessments in the San Joaquin-Tulare Basins, efforts will focus on five major activities:

1. Status assessment of mercury.

2. Status assessment of ground-water drinking water sources.

3. Assessment of water-quality trends in streams and ground water.

4. Topical study of transport of anthropogenic and natural contaminants to community supply wells.

5. Topical study of agricultural chemicals: sources, transport, and fate. 


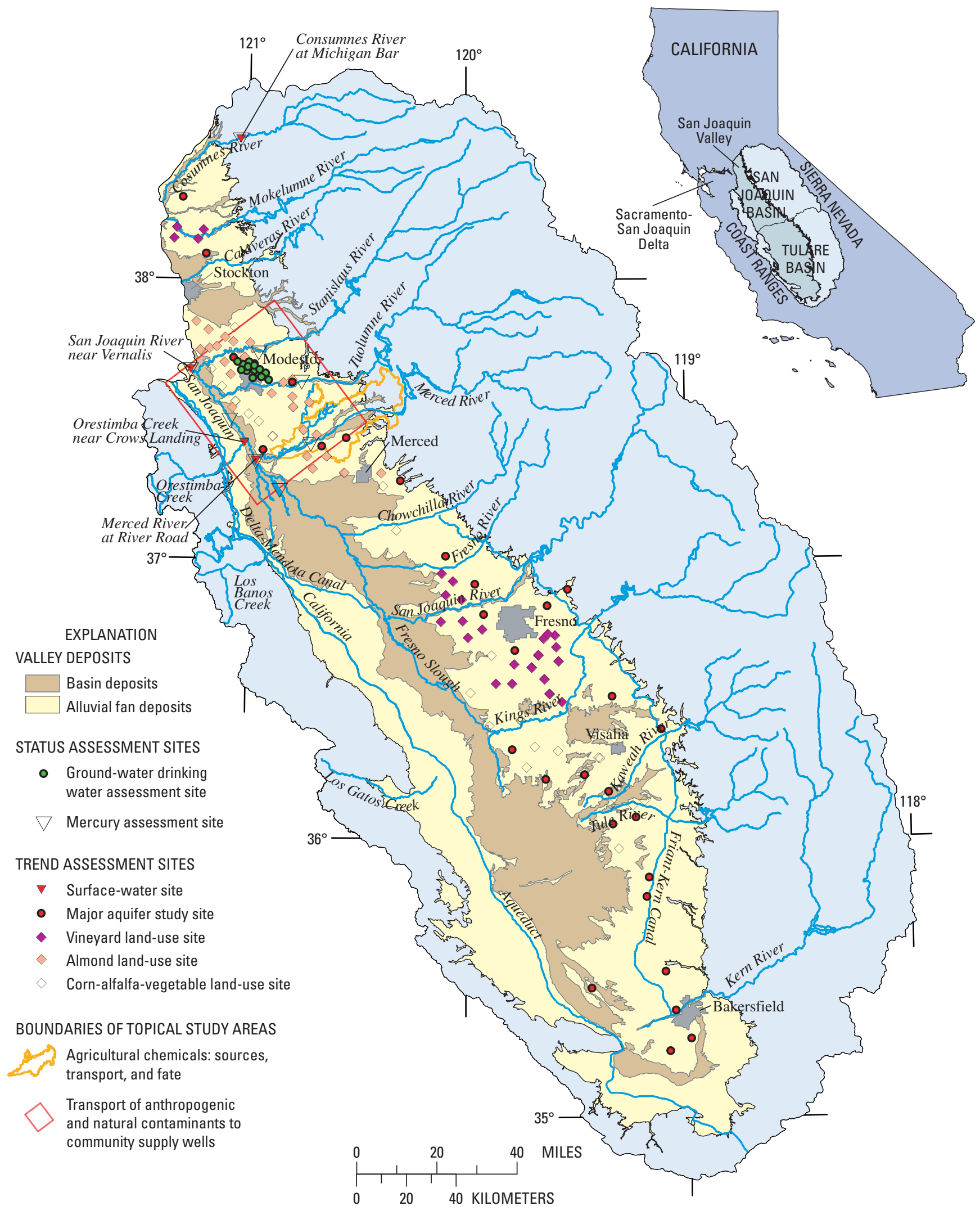

Figure 1. Locations of data collection sites for the second cycle studies of the San Joaquin-Tulare Basins, California. 


\section{Status Assessment of Mercury}

Mercury is one of the most widespread contaminants affecting our Nation's aquatic ecosystems. Fish consumption is the predominant route of exposure to methylmercury for humans and wildlife. Mercury sampling during the first cycle of NAWQA was limited to analyses of total mercury in fish livers and in streambed sediment.

The San Joaquin-Tulare Basins study unit participated in the NAWQA-wide mercury assessment in the summer of 2002, which involved analysis of water, bed sediment, and fish for methyl and total mercury at eight sites in the study area (fig. 1). Data from this assessment will be used by the mercury topical study to determine the occurrence and distribution of mercury in diverse environmental settings. These data will be used to contribute to a better understanding of the bioaccumulation of mercury in target game fish species and of mercury cycling in streams.

\section{Status Assessment of Ground-Water Drinking Water Sources}

Data analysis from the first cycle and cooperative projects with other agencies indicated the importance of assessing drinking water sources in selected locations as part of the NAWQA design. This entails sampling for contaminants in ground water that is directly used as a source of drinking water.

In the fall of 2002, source water from 15 community water-supply wells in the Modesto urban area were sampled and analyzed for major inorganics, organic carbon, trace elements, pesticides, volatile organic compounds (VOCs), isotopes for age dating, and selected microbes. Additional samples will be collected from the community water-supply wells during 2004.

\section{Assessment of Water-Quality Trends}

The primary goal of the trend component is to systematically assess long-term trends in the chemical and physical quality of the Nation's streams and ground water and in the ecological condition of the Nation's streams, and to relate observed trends and changes to probable causes.

\section{Streams}

Four surface-water sites, each representing a different part of the surfacewater system, are being sampled as part of the NAWQA trends network: San Joaquin River near Vernalis, Merced River at
River Road, Orestimba Creek near Crows Landing, and Cosumnes River at Michigan Bar (fig. 1). All except the Cosumnes River have been sampled since the beginning of the first cycle.

The San Joaquin River receives water from tributaries draining the Sierra Nevada and Coast Ranges, and except for streams discharging directly to the Sacramento-San Joaquin Delta, is the only surface-water outlet from the study area (about 31,200 square miles). The water quality of the San Joaquin River is of critical interest because it flows to the delta. Both the Delta-Mendota Canal, which supplies irrigation water to farms in the western San Joaquin Valley, and the California Aqueduct, which supplies drinking water to southern California, originate in the delta.

The Merced River is located in a large basin (about 1,383 square miles) on the east side of the San Joaquin Basin. A large reservoir in the basin stores clean water from the Sierra Nevada; water released from this reservoir is used for agriculture and hydropower, and to assist the migration of salmon and steelhead. Streamflow below the reservoir is supplemented by storm runoff in the winter and irrigation return flows during the spring and summer. About 56 percent of the basin below the reservoir is agricultural, thus, water quality of the Merced River is a valuable indicator of the impacts of agriculture on water quality in east side tributaries to the San Joaquin River.

Orestimba Creek is an ephemeral stream in a small agricultural basin (10.8 square miles) within the valley floor on the west side of the San Joaquin Basin. Streamflow results from storm runoff in the winter, and irrigation return flows in the spring and summer. During the winter, the creek can also receive runoff from the Coast Ranges, depending on the intensity and duration of storms, thus increasing the drainage area to 195 square miles. Orestimba Creek is representative of the small western tributaries to the San Joaquin River.

The Cosumnes River is in the northern part of the study area and drains directly to the Sacramento-San Joaquin Delta. The basin is about 536 square miles. The Cosumnes is essentially the last significant free-flowing river from the Sierra Nevada, with only minor regulation by a small upstream reservoir. Past mining activities in the Cosumnes River Basin occurred upstream but within the basin. The Cosumnes River is sampled upstream of most of the agricultural activity in the basin, and therefore is representative of a "reference" for unaffected water quality.

High-intensity sampling for the second cycle of NAWQA started in October 2001; sampling frequency ranged from every 2 weeks to monthly. In October 2003, sampling frequency was reduced to low-intensity sampling ( 8 to 9 times per year). Water samples are being analyzed for nitrogen and phosphorus nutrient species, major anions, pesticides, and suspended sediment. The assessment of the streams for ecological conditions include the collection of fish, benthic invertebrates, and algae and the characterization of instream and riparian habitat. The ecological assessments are done annually during the late summer.

\section{Ground Water}

Wells used in a major aquifer study (of the San Joaquin-Tulare Basins) and in three agricultural land-use studies conducted in the first cycle are being resampled as part of the ground-water trends assessment for the second cycle.

The area of the major aquifer study is defined by the extent of the eastern alluvial fans physiographic region, which has been intensively farmed and irrigated since the early 1900s. The large quantity of fertilizers and pesticides used in this area, the intense irrigation, and the generally permeable sediments have resulted in a history of ground-water contamination problems. Most of the population and ground-water use in the San Joaquin-Tulare Basins is in the eastern alluvial fans region.

The vineyard, almond, and cornalfalfa-vegetable land-use study areas are nested within the major aquifer study area. Vineyards and almonds continue to be valuable and dominant crops in the study area, ranking second and tenth, respectively, in total production and value in 2001 in the State. The corn-alfalfavegetable land-use group encompasses a large variety of crops and therefore a large variety of pesticide applications.

Thirty wells from each study were sampled in 2001 or 2002 . These wells will continue to be sampled on a decadal schedule. A subset of wells from each study will be sampled biennially to evaluate the temporal trends within the decadal sampling period. The subset of wells sampled biennially will be sampled seasonally from fall of 2003 to summer of 2004 to determine how much the water quality varies seasonally in these study areas. 


\section{Topical Study of Transport of Anthropogenic and Natural Contaminants to Community Supply Wells}

Data analysis from the first cycle and cooperative projects with other agencies indicate the importance of assessing drinking water sources as part of NAWQA. The Transport of Anthropogenic and Natural Contaminants to Community Supply Wells study is addressing the question, "What are the primary manmade and natural contaminant sources, aquifer processes, and well characteristics that control the transport and transformation of contaminants along flow paths to community supply wells in representative water-supply aquifers?"

The San Joaquin-Tulare Basins is one of eight areas across the Nation currently involved in this process-oriented study. The area of focus of this study is the valley floor around and including the city of Modesto (fig. 2). The specific objectives of the study are to:

1. Characterize the regional hydrogeologic setting and determine the dominant ground-water flow paths to community supply wells.

2. Evaluate dominant sources of contaminants contributing to community supply wells, including agricultural and urban contaminants, and geologic source areas for natural contaminants.
3. Develop an understanding of transport and transformation processes that affect anthropogenic and natural contaminants as they are transported to community supply wells.

Results from the status assessment of the sources of ground-water drinking water, the first cycle investigations, and other retrospective analyses are being evaluated in relation to sources of anthropogenic and natural contaminants. The pesticide database maintained by the State of California will be accessed for information on pesticide applications. Ancillary information such as geology, land-use, and census data, data on leaky underground fuel tanks, and data from the National Uranium Resource Evaluation Program will also be examined as surrogates for other chemical applications.

A regional ground-water flow model extending from just north of the Stanislaus River to south of the Merced River, west past the San Joaquin River, and east to the edge of the alluvial fans was developed to help characterize the regional flow system and determine the dominant ground-water flow paths to the community supply wells (fig. 2).

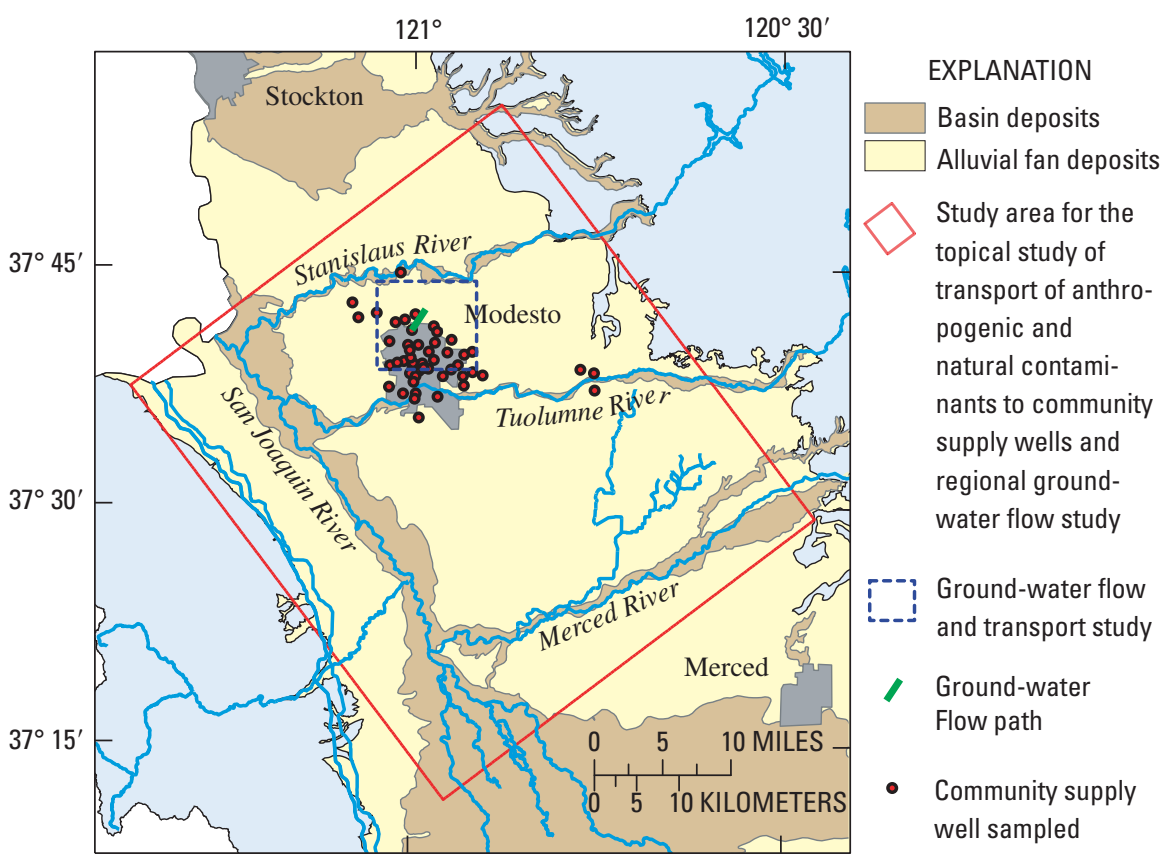

Figure 2. Study area for the topical study of transport of anthropogenic and natural contaminants to community supply wells in and around Modesto, California.
Using the information from the regional model and from the results of an evaluation of possible contaminants, a network of about 20 monitoring wells, located along flow paths and beneath selected sources of contaminants, will be installed between July 2003 and May 2004 (fig. 3) Continuous samples of the subsurface material are collected at selected intervals for solid-phase analysis and aquifer sediment characteristics. These wells will be sampled for a broad range of constituents (including age dating) to provide information on the areal distribution of contaminants in the local study area. Ground-water levels will be monitored in all wells; some wells will be instrumented with continuous measurement equipment.

A ground-water flow and transport model, encompassing a part of the urban Modesto area, will be developed (fig. 2). The model will be used to evaluate the relative importance of physical and chemical processes that affect the contaminants moving along dominant groundwater flow paths. Since the Modesto area is typical of urban areas in the San Joaquin Valley, this work can be useful for extrapolation to other urban areas.

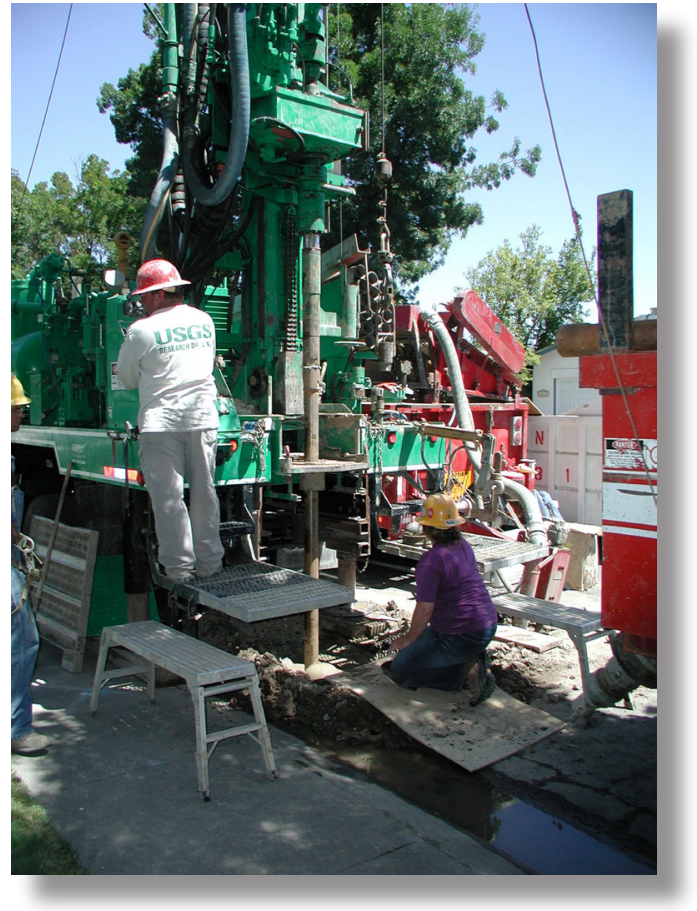

Figure 3. Drilling a monitoring well in Modesto, California. 


\section{Topical Study of Agricultural Chemicals: Sources, Transport, and Fate}

Agricultural land use has a large influence on the quality of surface- and ground-water in the United States. This topical study addresses the questions, "How do environmental processes and agricultural practices interact to affect the transport and fate of agricultural chemicals in the hydrologic system of nationally important agricultural settings, and what are the effects on water quality and implications for management of water resources?"

The San Joaquin-Tulare Basins is one of five areas across the Nation currently involved in this study. The study area is the Merced River Basin, located on the east side of the San Joaquin River (fig. 1). This basin is predominately agricultural in the valley floor part of the basin. Within the Merced River Basin, two areas will be studied intensively from 2003 to 2005: a ground-water flow path from an agricultural setting that terminates in the Merced River and the Mustang Creek subbasin (fig. 4). The objectives of the study are to:

1. Develop an annual mass budget for water and selected agricultural chemicals in the components of the hydrologic system.

2. Determine the residence times and rates of water and agricultural chemical transport among the components of the hydrologic system.

3. Identify the important chemical transformation and transfer processes for selected agricultural chemicals.

4. Use quantitative methods for interpreting, extrapolating, and predicting the fate and transport of water and selected agricultural chemicals, which can be applied to similar agricultural settings at a range of scales.

5. Interpret study results as to the implications for managing the water and water-quality impacts of agricultural systems.

Data on crop type and management practices, such as water-, pesticide-, and

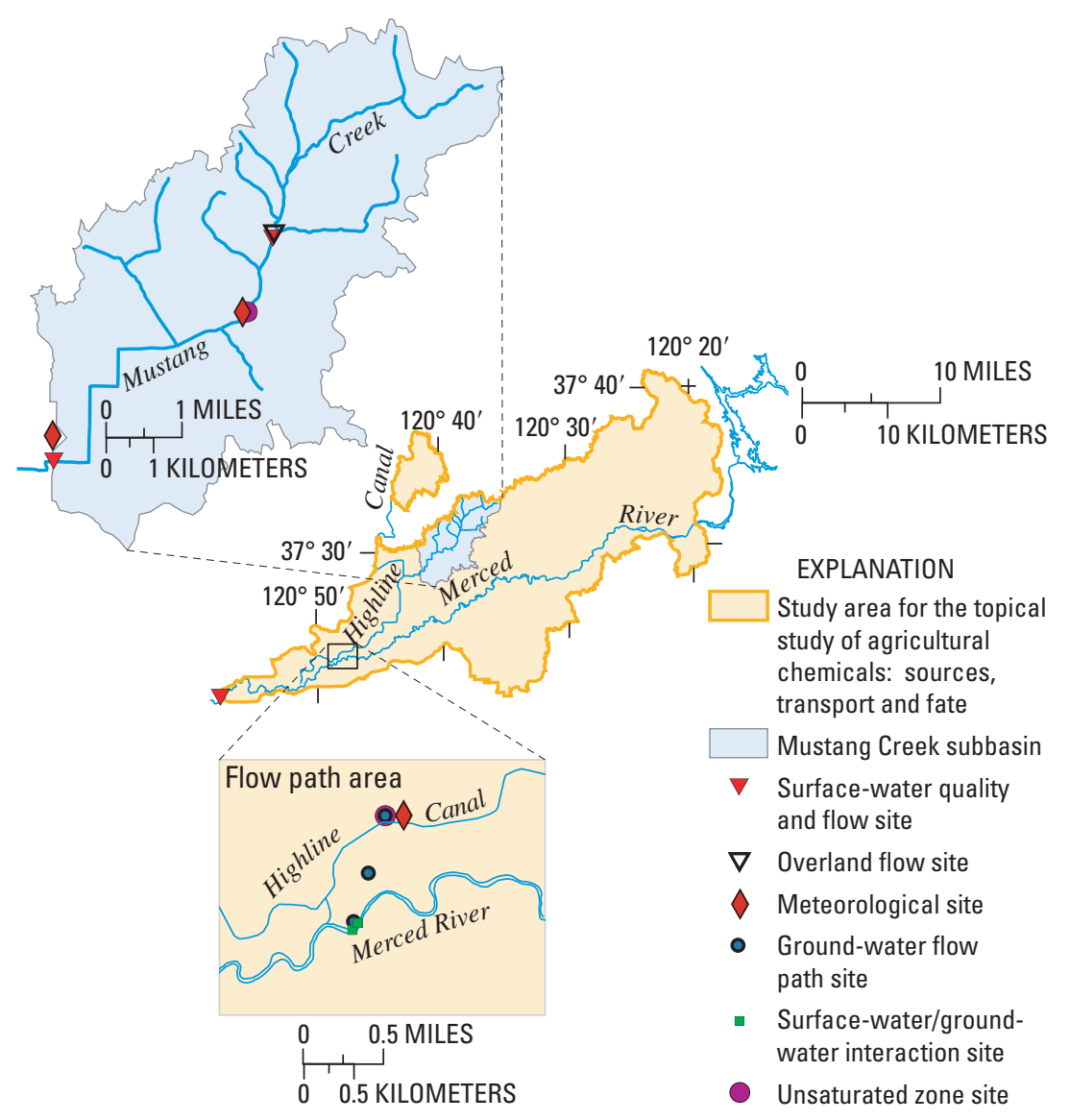

Figure 4. Study area for the topical study of agricultural chemicals: sources, transport, and fate of the Merced River Basin, California.

fertilizer-use, will be collected for the study area. The study can be categorized into three broad components of the hydrologic system: atmospheric, surface water, and ground water.

Two precipitation sites within the Mustang Creek subbasin are being sampled for targeted pesticides and their transformation products. A third site is being established on the ground-water flow path near the Merced River. These data, in combination with spatial meteorological data, will be used to calculate the areal distribution of chemicals to the watershed via rainfall.

Surface-water sites along Mustang Creek and a site near the mouth of the Merced River will be sampled and analyzed for nutrients, pesticides, suspended sediment, and other selected water-quality constituents. The Mustang Creek subbasin is being modeled to simulate surface-water flow. An overland flow site will characterize runoff from a specific field. Dye studies are being conducted during the rainy season to determine travel times along Mustang Creek. The primary goal of the surface-water assessments will be to identify temporal patterns in the concentrations of selected pesticides and nutrients and to relate these patterns to surface-water transport processes.

Activities relating to ground water are being focused on characterizing the movement of water and chemicals from the land surface through the unsaturated and saturated zones to surface water. Movement of water and chemicals through the unsaturated zone (between the land surface and the water table) will be estimated by measuring irrigation and evapotranspiration rates and by collecting subsurface water samples using lysimeters. These data will be used to develop simulations of unsaturated flow and chemical transformations to generate a better understanding of these processes at the local scale. 
Movement of water and chemicals through the aquifer system beneath the water table will be inferred using waterlevel measurements and water samples (for chemical and age-dating analyses) collected from several multi-depth monitoring wells installed along the general direction of ground-water flow toward the Merced River. These data will be used to calibrate a local-scale ground-water flow model. This local-scale model will utilize the results of the regional model developed for the topical studies.

Movement of ground water and chemicals into the Merced River will be inferred using a variety of data collection (fig. 5) and analysis techniques. Vertical hydraulic gradients will be determined using water-level measurements in multidepth monitoring wells within the river and riparian zone. Seepage rates and chemistry will be determined at several locations using seepage meters. Seepage rates and hydraulic characteristics of the riverbed will be determined using temperature measurements and simulations of heat transport.

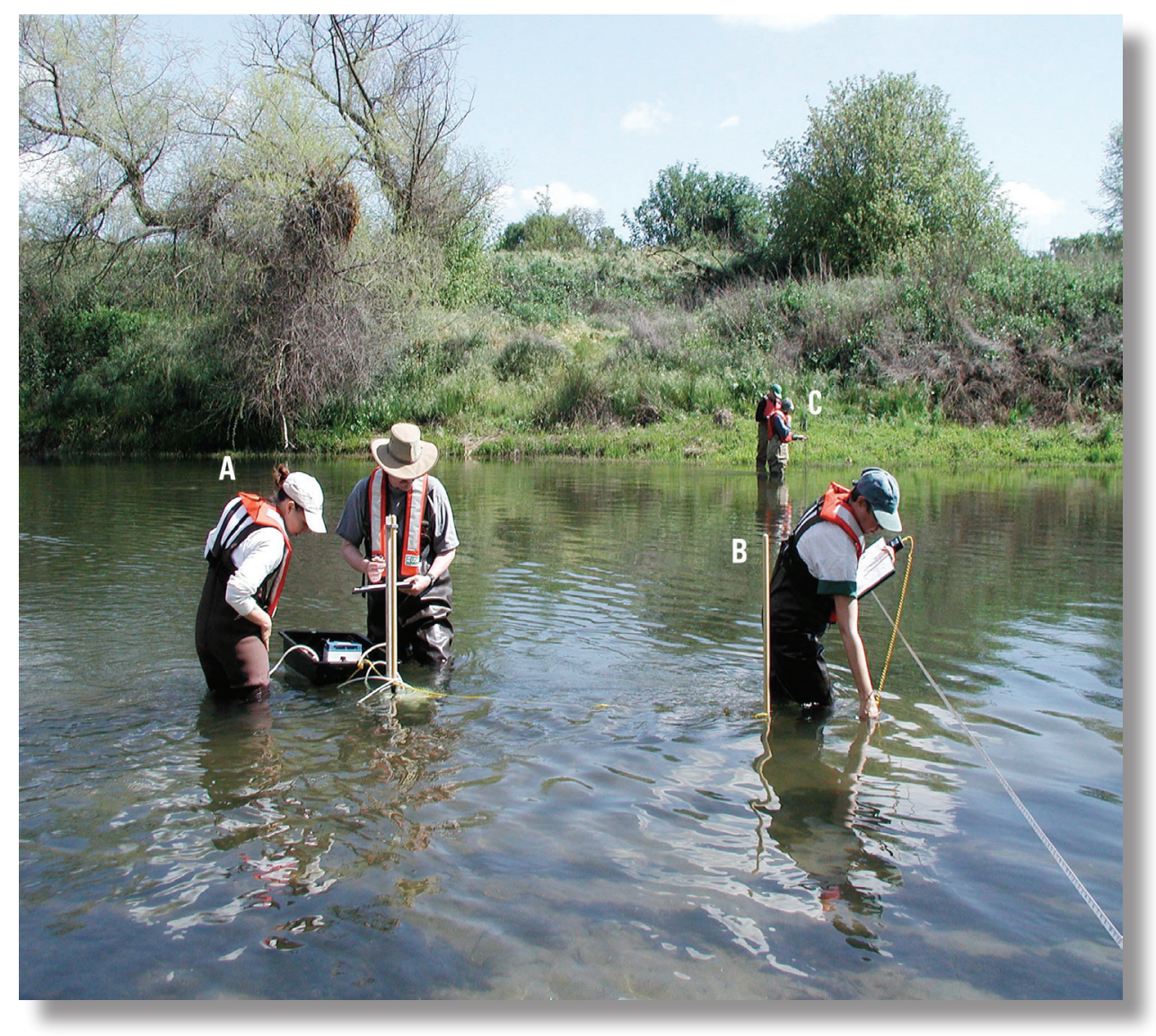
ticle size, percentage of organic matter,

\section{References Cited} wells along the ground-water flow path will include field parameters, pesticides, nutrients, major ions, and dissolved organic carbon. Selected samples at the surface-water/ground-water interaction sites will be age dated. At these sites, sediment core samples will also be collected and analyzed for bulk density, parsoil moisture, selected minerals, chloride, and nitrate. Denitrification rates will be assessed by injecting nitrate and a tracer into the riverbed and sampling periodically, noting the rate of nitrate disappearance.

The goal of this topical study is to estimate the flux of water and agricultural chemicals through the unsaturated zone, into the saturated zone, and between surface water and ground water, and to assess the chemical transformations that occur as the water moves through these different components of the hydrologic system.
Dubrovsky, N.M., Kratzer, C.R., Brown, L.R., Gronberg, J.M., and Burow, K.R., 1998, Water Quality in the San Joaquin-Tulare Basins, California, 1992-1995: U.S. Geological Survey Circular 1159, 38 p.

Gilliom, R.J., Hamilton, P.A., and Miller, T.L., 2001, The National Water-Quality Assessment Program-Entering a new decade of investigations: U.S. Geological Survey Fact Sheet 071-01, 6 p.

Gronberg, J.M., Dubrovsky, N.M., Kratzer, C.R., Domagalski, J.L., Brown, L.R., and Burow, K.R., 1998, Environmental setting of the San Joaquin-Tulare Basins, California: U.S. Geological Survey Water-Resources Investigations Report 97-4205, 45 p.

Hirsch, R.M., Alley, W.M., and Wilber, W.G., 1988, Concepts for a National Water-Quality Assessment Program: U.S. Geological Survey Circular 1021, $42 \mathrm{p}$.

by Jo Ann M. Gronberg, Charles R. Kratzer, Karen R. Burow, Joseph L. Domagalski, and Steven P. Phillips

For more information contact:

\author{
U.S. Geological Survey \\ Placer Hall, 6000 J Street \\ Sacramento, California 95819 \\ Telephone: (916) 278-3000
}

Home page: http://ca.water.usgs.gov/sanj/

Figure 5. U.S. Geological Survey scientists showing techniques used to measure $(A)$ direction of ground-water flow; (B) temperature below streambed, and (C) stream discharge. 